Oktafiani et al., Afr., J. Infect. Dis. (2018) 12 (2): $43-46$

https://doi.org/10.21010/ajid.v12i2.7

\title{
DETECTION OF HUMAN HERPESVIRUS-8 ANTIGEN IN HIV-INFECTED PATIENTS IN EAST JAVA, INDONESIA
}

\section{Devi Oktafiani ${ }^{1 *}$, Ni Luh Ayu Megasari ${ }^{1}$, Elsa Fitriana ${ }^{1}$, Nasronudin ${ }^{2}$, Maria Inge Lusida ${ }^{3,4}$, Soetjipto ${ }^{2,3,5}$}

${ }^{1}$ Doctoral Degree Program, Faculty of Medicine, Universitas Airlangga, Surabaya, Indonesia; ${ }^{2}$ Universitas Airlangga Hospital, Surabaya, Indonesia; ${ }^{3}$ Institute of Tropical Disease, Universitas Airlangga, Surabaya, Indonesia; ${ }^{4}$ Department of Medical Microbiology, Faculty of Medicine, Universitas Airlangga, Surabaya, Indonesia; ${ }^{5}$ Department of Medical Biochemistry, Faculty of Medicine, Universitas Airlangga, Surabaya, Indonesia.

*Corresponding Author's E-mail: devi.oktafiani-2015@fk.unair.ac.id

\begin{tabular}{|l|}
\hline \multicolumn{1}{|c|}{$\frac{\text { Article History }}{\text { March. 17, 2017 }}$} \\
Received: \\
Revised Received: Dec. 13, 2017 \\
Accepted: Dec. 13, 2017 \\
Published Online: June. 18, 2018 \\
\hline
\end{tabular}

\begin{abstract}
Background: Co-infection of human herpesvirus-8 (HHV-8) in HIV-positive people might cause Kaposi's sarcoma. Early detection of HHV-8 may prevent the onset of clinical manifestations. In Indonesia, detection of HHV-8 antigen in HIVpositive patients has yet to be reported. The intention of this research was to examine the presence of HHV-8 antigen in HIV-positive patients in East Java, Indonesia.

Material and Methods: 103 serum samples were collected from HIV-positive patients in Surabaya and Tulungagung, East Java, Indonesia. Serums were then tested for the presence of HHV-8 antigen by using sandwich ELISA.

Results: Human Herpesvirus-8 antigen was detected in 15 samples (14.5\%). The presence of HHV-8 infection in HIVpositive patients did not present differently in males and females and among different age groups. Human immunodeficiency virus-positive serum samples were collected from 23 homosexual men, 25 intravenous drug users (IVDUs) and 52 heterosexuals. In the male homosexual group, HHV-8 antigen was detected in 21.7\% (5/23) of the samples, while in the intravenous drug user group (IVDUs), $16 \%$ (4/25) of the samples were found to have HHV-8 antigen. Conclusion: This research found the presence of HHV-8 antigen in $14.5 \%$ of patients in East Java, Indonesia. It is recommended that patients with a positive result should receive further examination to detect any clinical manifestations related to HHV-8 infection, especially in the form of Kaposi's sarcoma lesions, so that the illness can be appropriately managed.
\end{abstract}

Key Words: HHV-8 antigen, HIV-positive, East Java, Indonesia.

\section{Introduction}

The human immunodeficiency virus (HIV) primarily attacks $T$ helper (CD4+) lymphocytes. The human immunodeficiency virus (HIV) infection causes the immune system to weaken, so that the host becomes more susceptible to various infections and malignancies (Grant et al., 2005). One common co-infection found in people living with HIV/AIDS is a herpesvirus infection, including herpes simplex virus types 1 and 2 (HSV-1, HSV-2), varicella zoster virus, cytomegalovirus (CMV), Epstein-Barr virus (EBV), herpesviruses 6 and 7, and human herpesvirus 8 (HHV-8 or Kaposi sarcoma-associated herpesvirus [KSHV]) (Brooks et al., 2013). HHV-8 infection in HIV/AIDS patients may cause Kaposi's Sarcoma (Dourminishev et al., 2003). Kaposi's sarcoma is a tumor developed from cells on lymph nodes or in blood vessels, and can also develop in other parts of the body (Dourminishev et al., 2003).

HHV-8 or KSHV, the only known human herpesvirus (rhadinovirus), is the most recently discovered tumor virus (Viejo-Borbolla et al., 2003). HHV-8 has a diameter of $140 \mathrm{~nm}$ and a genome of between approximately $125 \mathrm{~kb}$ (Burbelo et al., 2015), $165 \mathrm{~kb}$ (Brooks et al., 2013) and $170 \mathrm{~kb}$ (Russo et al., 1996). The virus has a double stranded linear DNA and icosahedral capsid envelope (Viejo-Borbolla et al., 2003). It is covered by a tegument containing protein, and closed during 
budding of the cell. The membrane is derived from outer envelope of lipid membrane from various host and specific virus glycoprotein (Swaminathan, 2003).

Kaposi's sarcoma is more prevalent in immunosuppressed patients than healthy people. It often occurs in people with Jewish, Mediterranean, African, and Middle Eastern origins. Sero-epidemiological evidence of HHV-8 infection can be used to reflect the epidemiology of Kaposi's sarcoma (Grulich et al., 2001). Ablashi and colleagues' research reports that in 1999, seropositive prevalence of HHV-8 infection in general population of USA, Northern Europe, and Asia was only around zero to five percent; this was also the case in a seroepidemiological study in Malaysia, Hong Kong, and Sri Lanka where the seroprevalence of HHV-8 was found to be around 3,7\%. However, a higher prevalence was found in Southern Europe, around five to ten percent. (Ablashi et al., 1999). There has been no data regarding viremia detection using ELISA method and no epidemiological reporting on the prevalence of HHV-8 infection in Indonesia. The aim of this study was to correct this omission with an examination of the presence of HHV-8 antigen in HIV-positive patients in East Java, Indonesia.

\section{Materials and Methods}

This study was approved by the Ethics Committee of Universitas Airlangga Hospital. A hundred and three serum samples were collected from HIV-positive patients in Universitas Airlangga Hospital, Surabaya and Dokter Iskak Tulungagung General Hospital, East Java, Indonesia. The inclusions criteria are positive HIV infected with naïve or treated with antiretroviral, all age (in this case 7-5 years old, and the mean age is 37 years old). Exclusion criteria in this study were patients who did not agree to follow the study. Informed consent was obtained from each patient prior to sample collection. Patients were also asked to complete a questionnaire to provide general information and the possible route of transmission. The patients were then subjected to an HHV-8 antigen test using sandwich ELISA (Abbexa, Cambridge, UK), according to manufacturer instructions. Data obtained were analyzed using statistical software (SPSS version 21.0).

\section{Results}

HIV-positive patients involved in this study comprised of 64 males and 39 females, with a mean age of 37 years (range 7-64 years). This research showed that 15 of 103 samples (14.56\%) were found to be HHV-8 antigen positive. In regards to patients' gender, ten men (15.6\%) and five women (12.8\%) tested positive. The presence of HHV-8 antigen did not show any significant differences in age $(p=0.05)$ and gender $(p=0.78)$. HHV-8 infection in homosexual men was $21.7 \%$, while $16 \%$ intravenous drug users (IVDUs) were positive.

Table 1. Determinants of HHV-8 infection in HIV positive patients

\begin{tabular}{llll}
\hline Characteristic & $\mathrm{N}$ & $\begin{array}{l}\text { HHV-8 positive } \\
\mathrm{N}(\%)\end{array}$ & $\begin{array}{l}\mathrm{P} \text { value } \\
\mathrm{p}<0,05, \text { S (Significant), NS } \\
\text { (Not Significant) }\end{array}$ \\
\hline Age group (years) & & & \\
\hline A: $\leq 30$ & 31 & $4(12,9 \%)$ & \\
$\mathrm{B}: 31-40$ & 35 & $7(20 \%)$ & $\mathrm{p}=0,5$ (NS) \\
$\mathrm{C}:>40$ & 37 & $4(10,8 \%)$ & \\
\hline Sex & & & $\mathrm{p}=0,78(\mathrm{NS})$ \\
\hline Male & 64 & $10(15,6 \%)$ & \\
Female & 39 & $5(12,8 \%)$ & $\mathrm{p}=0,5(\mathrm{NS})$ \\
\hline Sexual orientation & & & \\
\hline Homo/bisexual & 25 & $4(16 \%)$ & $\mathrm{p}=0,6$ (NS) \\
Heterosexual & 78 & $11(14.1 \%)$ & \\
\hline Marital status & & & \\
\hline Married & 68 & $10(15,6 \%)$ & \\
Not married & 35 & $5(12,8 \%)$ & \\
\hline
\end{tabular}

\section{Discussion}

The results of the study conducted in East Java, Indonesia are an interesting comparison with other studies around the world. It must be reiterated here that the participants in the study were not screened for Kaposis sarcoma and the ELISA method was not used to collect the data regarding HHV-8 viremia. While the presence of HHV-8 antigen was detected in $14.56 \%$ of HIV-positive patients in East Java, Indonesia, previous studies in Xinjiang, China (Zhang et al., 2012), Nigeria (Ogoina et al., 2011) and Cameroon (Mbondji-Wonje et al., 2013) showed a greater prevalence, that is 
$31.2 \%, 62 \%$ and $70 \%$ respectively. Human herpesvirus 8 antigen was detected in $21.7 \%$ HIV-positive homosexual men. A study in Thailand reported the presence of HHV-8 lytic antigen in 12\% HIV-positive homosexual men, $16 \%$ heterosexual men, and 9\% IVDUs (Ayuthaya et al., 2002). HHV-8 without KS in serum samples are detected 4\% and AIDS-KS are $42.8 \%$ in Brazil (Machado et al., 2016). Detection of herpes virus DNA in lymphocytes could possibly represent latent infection, while detectable DNA in serum or plasma is usually associated with disease (Polstra et al., 2003). In HIVpositive patients without Kaposi Sarcoma, $4 \%$ were positive using PCR method. These patients certainly present a higher risk of developing AIDS-KS (Machado et al., 2016).

Kaposi's sarcoma was the most common neoplasm found in patients infected with HIV. Kaposi's sarcoma is a tumor of blood vessels, which appears as lesions on the skin, and then spreads to other organs. It is noted here that there has been a decrease in the incidence of Kaposi's with other opportunistic illnesses, since the introduction of highly active antiretroviral therapy (HAART) (Jacobson et al., 1999). This downward trend is most likely due to secondary effects of antiretroviral therapy on the immune system (Cattelan et al., 2001 dan De Milito et al., 1999) rather than direct effect to HHV-8 (Kedes dan Ganem, 1997).. A study utilizing polymerase chain reaction (PCR) demonstrated that HHV-8 was detected in more than $90 \%$ of Kaposi's sarcoma lesions (Mendez et al., 1998). Prospective studies indicated that the detection of HHV-8 could predict the development of Kaposi's sarcoma in asymptomatic subjects (Whitby et al., 1995 dan Moore et al., 1996). Several studies using different serological tests found that almost $100 \%$ patients with different clinical forms of Kaposi's sarcoma had a high titer of the HHV-8 antibody, which had been detected before the appearance of clinical lesions of Kaposi's sarcoma (Whitby et al., 1995; Gao et al., 1996 dan Moore et al., 1996). Current evidence suggests that HHV-8 infection is a prerequisite in the pathogenesis of Kaposi's sarcoma, but factors relating to the host immuno-deficiency may greatly increase the incidence of Kaposi's sarcoma among subjects infected with HHV-8.

The presence of HHV-8 infection in HIV-positive patients is possibly related to the risk of developing opportunistic diseases, including Kaposi's sarcoma (classic, AIDS-related KS, endemic and iatrogenic) and other proliferative diseases, such as primary effusion lymphoma and multicentric Castleman disease. Among immuno-competent people, only a small proportion of HHV-8 infections develop into Kaposi sarcoma. Various tests have detected HHV-8 antibodies in the majority of asymptomatic individuals with increased tumor risk, including HIV-positive homosexual men (Martin et al., 1998), adults from Italy and various regions of sub-Saharan Africa (Sitas et al., 1999; Calabro et al., 1998), and some low risk people, such as blood donors from the UK, USA, and Jamaica (Simpson et al., 1996; Engels et al., 1999).

\section{Conclusion}

The presence of HHV-8 antigen was found in $14.5 \%$ of the HIV-positive patients who participated in this study which is the first of its kind in Indonesia. Based on these results found in patients in East Java, further investigations should be conducted on patients living with HIV. This would assist with early detection and subsequent management of any clinical manifestations related to HHV-8 infection, especially in the form of Kaposi's sarcoma lesion.

Conflict of Interest: The authors declare no conflict of interest.

Acknowledgements: Thanks to LSM Mahameru, KDS Couple Community, and all the colleagues who have helped in this study.

\section{References}

1. Ablashi, D., Chatlynne, L., Cooper, H., Thomas, D., Yadav, M., Norhanom, A.W., Chandana, A.K., Churdboonchart, V., Kulpradist, S.A., Patnaik, M., Liegmann, K., Masood, R., Reitz, M., Cleghorn, F., Manns, A., Levine, P.H., Rabkin, C., Biggar, R., Jensen, F., Gill, P., Jack, N., Edwards, J., Whitman, J., Boshoff, C (1999). Seroprevalence of human herpesvirus-8 (HHV-8) in countries of Southeast Asia compared to the USA, the Caribbean and Africa. British Journal of Cancer. 81: 893-897.

2. Ayuthaya, P.I.N., Katano, H., Inagi, R., Auwanit, W., Sata, T., Kurata, T., and Yamanishi, K. (2002). The seroprevalence of human herpesvirus 8 infection in the Thai population. Southeast Asian Journal Tropical Medicine Public Health,, 33 (2): 297-305

3. Brooks, G.F., Carol, K.C., Butel, J.S., Morse, S.A., Mietzner, T.A. (2013). Jawetz, Melnick, \& Adelberg's Medical Microbiology: Twenty-six Edition ed. USA: McGraw Hill, p.467-488

4. Calabro, M.L, Sheldon, J., Favero, A., Simpson, G.R., Fiore, R., Gomes, E., Angarano, G., Chieco-Bianchi, L. and Schulz, T.F. (1998). Seroprevalence of Kaposi's sarcoma-associated herpesvirus/human herpesvirus 8 in several regions of Italy. Jounal of Human Virology., 1: 207-213 
5. Cattelan, A., Calabro, M., Gasperini, P., Aversa, S., Zanchetta, M., Meneghetti, F., De Rossi, A., Chieco-Bianchi, L. (2001). Acquired immunodeficiency syndrome-related Kaposi's sarcoma regression after highly active antiretroviral therapy: biologic correlates of clinical outcome. Journal of the National Cancer Institute Monographs. 28:44-49.

6. De Milito, A., Catucci, M., Venturi, G., Romano, L., Incandela, L., Valensin, P.E., Zazzi, M. (1999). Antiretroviral therapy with protease inhibitors in human immunodeficiency virus type 1- and human herpesvirus 8-coinfected patients. Journal of Medical Virology. 1999;57:140-144.

7. Engels, EA, Eastman, H., Ablashi, DV, Wilks, RJ, Braham, J, and Manns, A. (1999). Risk of transfusion-associated transmission of human herpesvirus 8. Journal of the National Cancer Institute. 91, 1773-1775

8. Gao, SJ, Kingsley, L., Li, M., Zheng, W., Parravicini, C., Ziegler, J., Newton, R., Rinaldo, C.R., Saah, A., Phair J, Detels, R, Chang, Y, Moore, P.S. (1996). KSHV antibodies among Americans, Italians and Ugandans with and without Kaposi's sarcoma. Nature Medicine 2:925-928

9. Grulich, A., Rawlinson, W.D., Cunningham, P. (2001). Human herpesvirus 8: a newly described sexually transmissible infection. Venereology 14, 174-180

10. Jacobson, L.P., Yamashita, T.E., Detels, R., Margolick, J.B., Chmiel, J.S., Kingsley, L.A., Melnick, S., Mulnoz, A. (1999). Impact of potent antiretroviral therapy on the incidence of Kaposi's sarcoma and non-Hodgkin's lymphomas among HIV1- infected individuals. Multicenter AIDS Cohort Study. Journal of Acquire Immune Deficiency Syndrome;21(Suppl 1):S34-41.

11. Kedes, D.H. and Ganem, D. (1997). Sensitivity of Kaposi's sarcoma-associated herpesvirus replication to antiviral drugs. Implications for potential therapy. The Journal of Clinical Investigation; 99:2082-2086.

12. Machado, I., Farias, K., Pereira, M., Freitas, P., Fonseca, B. (2016). Human herpesvirus 8 (HHV-8) detected by nested polymerase chain reaction (PCR) in HIV patients with or without Kaposi's sarcoma. An analytic cross-sectional study. Sao Paulo Medical Journal. 2016; 134(3):187-192

13. Martin, J.N., Ganem, D.E., Osmond, D.H., Page-Shafer, KA, Macrae, D. and Kedes, D.H. (1998). Sexual transmission and the natural history of human herpesvirus 8 infection. The New England Journal of Medicine; 338, 948-954

14. Mbondji-Wonje, C., Ragupathy, V., Lee, S., Wood, O., Awazi, B., and Hewlett, I.K. (2013). Seroprevalence of Human Herpesvirus-8 in HIV-1 Infected and Uninfected Individuals in Cameroon. Viruses 2013, 5, 2253-2259

15. Mendez, J.C., Procop, G.W., Espy, M.J., Paya, C.V., Smith, T.F. (1998). Detection and semiquantitative analysis of human herpesvirus 8 DNA in specimens from patients with Kaposi's sarcoma. Journal of Clinical Microbiology; 36:2220-2222

16. Moore, P.S., Kingsley, L.A., Holmberg, S.D., Spira, T., Gupta, P., Hoover, D.R., Parry, J.P., Conley, L.J., Jaffe, H.W., Chang, Y. (1996). Kaposi's sarcoma-associated herpesvirus infection prior to onset of Kaposi's sarcoma. AIDS 10:175-180

17. Ogoina, D., Onyemelukwe, G., Musa, B,O., Babadoko, A. (2011). Seroprevalence and determinants of human herpes virus 8 infection in adult Nigerians with and without HIV-1 infection. African Health Sciences 2011; $11(2): 158-162$

18. Polstra, A.M., Van Den Burg R., Goudsmit, J., Cornelissen, M. (2003). Human herpesvirus 8 load in matched serum and plasma samples of patients with AIDS-associated Kaposi's sarcoma. Journal of Clinical Microbiology. 2003;41(12):54885491.

19. Russo, J.J., Bohenzky, R.A., Chien, M-C., Chen, J., Yan, M., Maddalena, D., Parry, J.P., Peruzzi, D., Edelman, I.S., Chang, Y., and Moore, P.S. (1996). Nucleotide sequence of the Kaposi sarcoma-associated herpesvirus (HHV8). Proceeding of the National Academy of Sciences of the United States of America. 93 (25), 14862-14867.

20. Simpson, G.R., Schulz, T.F., Whitby, D., Cook, P.M., Boshoff, C., Rainbow, L., Howard, M.R., Gao, Shou-Jiang., Bohenzky, R.A., Simmonds, P., Lee, C., Ruiter, A., Hatzakis, A., Tedder, R.S., Weller, I., Weiss, R.A., Moore, S. (1996). Prevalence of Kaposi's sarcoma associated herpesvirus infection measured by antibodies to recombinant capsid protein and latent immunofluorescence antigen. Lancet, 349, 1133-1138

21. Sitas, F., Carrara, H., Beral, V., Newton, R., Reeves, G., Bull, D., Jentsch, U., Pacella-Norman, R., Bourboulia, D., Whitby, D., Boshoff, C. and Weiss, R. (1999). Antibodies against human herpesvirus 8 in black South African patients with cancer. The New England Journal of Medicine; 340, 1863-1871

22. Swaminathan, S. (2003). Molecular biology of Epstein-Barr virus and Kaposi's sarcoma-associated herpesvirus. Seminars in Hematology; 40, 107-115.

23. Viejo-Borbolla, A., Ottinger, M., Schulz, T.F. (2003). Human herpesvirus 8: Biology and role in the pathogenesis of Kaposi's sarcoma and other AIDS-related malignancies. Current HIV/AIDS Reports. 5, 169-175.

24. Whitby, D., Howard, M.R., Tenant-Flowers, M., Brink, N.S., Copas, A., Boshoff, C., Hatzioannou, T., Suggett, F.E., Aldam, D.M., Denton, A.S. (1995). Detection of Kaposi sarcoma associated herpesvirus in peripheral blood of HIVinfected individuals and progression to Kaposi's sarcoma. Lancet 346:799-802

25. Zhang, T., Shao, X., Chen, Y., Minhas, V., Wood, C., and He, N. (2012). Human Herpesvirus 8 Seroprevalence, China, Virology Papers. Paper 238. 